\title{
Avirulence gene based RFLP and rep-PCR distinguish the genetic variation of Xanthomonas oryzae pv. oryzae pathotypes in Bangladesh
}

\author{
Mohammad Mahbubul Haque ${ }^{1}$, Md. Mostafa Masud ${ }^{2}$, Samrin Bashar ${ }^{2}$, Muhammad Iqbal Hossain ${ }^{2}$, Md. Zahangir \\ Alam $^{2} \&$ Md. Rashidul Islam ${ }^{2}$
}

${ }^{1}$ Plant Pathology Division, Bangladesh Institute of Nuclear Agriculture (BINA), Mymensingh-2202, Bangladesh

${ }^{2}$ Plant Bacteriology and Biotechnology Laboratory, Department of Plant Pathology, Bangladesh Agricultural University, Mymensingh-2202, Bangladesh

*Email: rashidul.islam@bau.edu.bd

\section{OPEN ACCESS}

\section{ARTICLE HISTORY}

Received: 04 July 2021

Accepted: 13 November 2021

Available online

Version 1.0: 01 January 2022

\section{Check for updates}

\section{Additional information}

Peer review: Publisher thanks Sectional Editor and the other anonymous reviewers for their contribution to the peer review of this work.

Reprints \& permissions information is available at https://horizonepublishing.com/ journals/index.php/PST/open_access_policy

Publisher's Note: Horizon e-Publishing Group remains neutral with regard to jurisdictional claims in published maps and institutional affiliations.

Indexing: Plant Science Today, published by Horizon e-Publishing Group, is covered by Scopus, Web of Science, BIOSIS Previews, Clarivate Analytics, etc. See https://

horizonepublishing.com/journals/index.php/ PST/indexing_abstracting

Copyright: ( $)$ The Author(s). This is an openaccess article distributed under the terms of the Creative Commons Attribution License, which permits unrestricted use, distribution and reproduction in any medium, provided the original author and source are credited (https://creativecommons.org/licenses/ by/4.0/)

\section{CITE THIS ARTICLE}

Haque M M, Md. Masud M M, Bashar S, Hossain M I, Md. Alam Z M, Islam M R. Avirulence gene based RFLP and rep-PCR distinguish the genetic variation of Xanthomonas oryzae pv. oryzae pathotypes in Bangladesh. Plant Science Today. 2022;9(1):29-40. https:// doi.org/10.14719/pst.1369

\begin{abstract}
Bacterial blight (BB) caused by $X$. oryzae pv. oryzae is one of the devastating diseases of rice mostly in Asia. Genomes of $X$. oryzae pv. oryzae is highly variable due to rearrangement of the large contents of transposable elements and dynamic changes of $X$. oryzae pv. oryzae population regulated efficiency of the control measures used for BB management of rice worldwide. In this study, genetic variation of $X$. oryzae pv. oryzae pathotypes of Bangladesh was studied using aviruelnce gene based RFLP and rep-PCR techniques aimed to formulate pathogen targeted effective control measures against $\mathrm{BB}$ of rice. Eight pathotypes of $X$. oryzae pv. oryzae field isolates were identified based on their reactions against 10 Near Isogenic Lines (NILs). Among eight pathotypes, pathotypes IV and V contained higher number of isolates which were $30.13 \%$ and $23.01 \%$ respectively while pathotype VIII revealed as minimum containing only $2.51 \%$ of total isolates. These eight pathotypes were studied for their genetic variation by RFLP using avrBs3 repeat domain as probe. The results conceded that Bangladeshi $X$. oryzae pv. oryzae strains seem carrying a minimum of two and maximum of nine avrBs 3 family genes homologs. The resistance phenotype on IRBB7 and IRBB10 NILs also indicated presence of two major avrBs3 family genes viz. avrxa7 and avrXa10 in some pathotypes. Relationship of phylogenicity exhibited that $X$. oryzae pv. oryzae pathotypes assorted into two RFLP haplotypes as well as these haplotypes are largely distributed in Bangladesh. Phylogenetic analyses carried out by (REP, ERIC), rep-PCR and BOX depicted the presence of two main molecular haplotypes of $X$. oryzae pv. oryzae pathotypes. The relationship between pathotypes and molecular haplotypes of $X$. oryzae pv. oryzae in Bangladesh indicated that the same lineage possesses different pathotypes and different lineage possesses different pathotypes. The results indicated that eight different pathotypes might have originated from common inherited haplotypes with a wide genetic variation.
\end{abstract}

\section{Keywords \\ RFLP, Rep-PCR, Pathotypes}

\section{Introduction}

Co-evolution of reciprocal, "arms race" like relationship between bacterial pathogens and their hosts for adaptation has been observed during plantmicrobe interactions $(1,2)$. Bacterial pathogens overcome host defence or to establish successful infection in novel hosts through the development of new virulence factors such as effectors by maintaining a high level of ge- 
nomic polymorphism (3). A number of genetic factors such as gene insertion, deletion, point mutations, duplication, fission, fusion and wide range of genomic reorganization were accounted for extreme levels of genomic plasticity within several bacterial populations (4). A genetic process named horizontal gene transfer is fundamental for genomes to get novel DNA segments from remotely more or less similar organism through a number of process like conjugation, transduction and transformation as well as which booms genetic variability of bacteria (5). To coherent evaluation of mechanism and potentiality of pathogenic bacteria, the level of genetic variation must be analysed deeply (6).

A vascular pathogen named Xanthomonas oryzae pv. oryzae is the causal agent of Bacterial blight (BB) disease of rice $(7,8)$ is one of the utmost devastating disease of rice throughout the globe (9). $X$. oryzae pv. oryzae (Xoo) is a round-ended, rod-shaped, gram-negative bacterium whose cells vary in length and are motile by means of a single polar flagellum. Colonies on nutrient broth yeast extract media containing glucose are round, convex, mucoid and yellow in colour due to the development of the pigment Xanthomonadin, the characteristic of the genus (10). Extreme rain, humidity and temperature are having been designated to be significant factors creating larger amount of disease incidence and severity of this disease (11). Normally, in different growth stages of rice plant BLB appears, disease symptoms predominantly exhibit on leafs showing leaf blight or revealing wilting symptoms of young plants which has been known as Kresek, to infect such way, wound or water pores are served as a prime invading option for the pathogen $X$. oryzae pv. oryzae lesions with wavy edges emerge from the leaf tip and margins and then coalesce and enlarge in size, turn yellow, and then ultimately dying of the plant (12). 20 to $40 \%$ reduction of yield was accounted when plants infected at tillering stage with the highest rate (13). Up to 50\% yield reduction was also manifested in the early detection of bacterial blight disease in rice (14). Throughout the last few years, a serious BB epidemic happened in many areas of Bangladesh with substantial yield losses of around $50-70 \%$ especially in irrigated hybrid varieties possibly due to the emergence of new races of its pathogen (15). It has been reported the pathogenic variability of $X$. oryzae pv. oryzae in Bangladesh $(16,17)$. Twelve races of the $X$. oryzae pv. oryzae have been identified until 1995 in Bangladesh and the study indicated that some aggressive strains of Xoo occur in Bangladesh (16). Severe outbreak was observed in Bangladesh during the season of Boro 2007-2008 in both hybrid and inbred varieties (18). Bacterial blight is prevalent in both tropical and temperate areas and is endemic to much of Asia and parts of West Africa. In Asia specifically in Bangladesh, this disease occurs destructively during the monsoon (14) and it is a serious threat to agriculture and global food security (19). The diseases become one of the most devastating of rice because of the extensive cultivation of nitrogenresponsive modern rice cultivars (13). Damage due to $B B$ increased significantly following the widespread cultivation of high yielding and nitrogen-responsive dwarf hybrid varieties of rice in the 1960s (20).

However, several practices are included in controlling BB include biological control, chemical control, cultural methods, host genetic resistance and disease forecasting all around the globe (21). In Bangladesh, pathotypic and genotypic analyses were carried in some selected ricegrowing areas during the last few years and around 24 distinct pathotypes were detected around four years ago (15, 22). The results also revealed an admixture of the $X$. oryzae pv. oryzae races in the North to Mid-eastern districts of the country and indicated the existence of widespread genetic variation such as physiological, morphological and biochemical differences among Xoo strains (23). Another significant factor described was host-pathogen interactions ultimately modified in the pathogenic structures through mutation process accounted for high degree of DNA polymorphism and also observed that molecular variation was utmost between strains of several virulence phenotype (15). Genetic variation mainly influenced by widespread cultivation of rice varieties as pathogen is exceedingly dynamic in nature thus a shift in pathogen population structure and varieties possessing several resistance genes have transformed into susceptible cultivars against BB in prevalent rice producing areas of the world (6). Regional variation and diversity of $X$. oryzae pv. oryzae (Xoo) was remarkable in Asia because of polymorphic virulent strains (24). A single crop cycle leads to the modification in pathogen population structure through either recombination or mutation to adapt itself in several unfavourable ambience (25).

Therefore, distribution of resistant cultivars containing foremost resistance $(R)$ genes by the breeding programme could be the effective method to control BB. Still now, against bacterial blight 42 resistant genes has been studied coming from japonica varieties, indica cultivars as well as a number of resembling wild species such as 0 . officinalis, 0 . rufipogon, 0 . minuta and 0 . longistaminata (26-28). Due to overused of few resistance genes which might triggered the selection of new pathogenic races of the isolates followed by the selection of resistant host plants when a crop cycle is fully complete. Thus, this activity initiates either mutation or recombination changing the population arrangement of pathogen to accustom itself to the novel resistant host and changes of associated environment. Through several members of the avrBs3/pthA family in numerous strains or races, virulance disintegration is seem to be mediated. In Korean strain (KACC10311), 15 members are included in the family of $a v r B s 3 / p t h A$ indicated by genome sequence (29), 19 in USA (PXO99A) (30) and 17 in Japan (MAFF311018) (31). Moreover, Xoo African strains hold up to eight members of avrBs3/pthA and on the other hand, in a number of Asian strains, 16 copies were identified excluding Bangladesh $(32,33)$.

To evaluate the $X$. oryzae pv. oryzae strains globally and analyze the molecular haplotyping excluding Bangladeshi strains, two different approaches have been manifested those are polymerase chain reaction (rep-PCR) with repetitive sequence-based and RFLP (Restriction fragment length polymorphism) (34). Identification and functional 
characterization of avrBs3 family members genes in many Xanthomonas spp. more importantly in $X$. oryzae pv. oryzae have been reported to clarify the relation between races and genotypes $(4,35)$. AvrBs3 family proteins contains a central repeat domain, a nuclear localization signals (NILs) and an acidic transcriptional activation domain (36). Generally, the repeat number at specific position determines host specificity or adaptation to virulence. It is possible that the evolution of the 102-bp repeat unit is related to the mechanisms of virulence evolution in $X$. oryzae pv. oryzae under selection pressure by host $R$ genes. To unravel the relatiosnship between virulence phenotypes and the genotypes of Bangladeshi $X$. oryzae pv. oryzae races, the present study was designed to identify copy numbers and distribution patterns of avrBs3 family genes in X. oryzae pv. oryzae isolates in Bangladesh using RFLP analyses with avrBs3 family gene as probe. Repetitive sequence-based rep-PCR (polymerase chain reaction) analyses have been demonstrated to assess molecular haplotyping and evolution of $X$. oryzae pv. oryzae strains worldwide (34) except strains from Bangladesh. Epidemiological experiments of numerous mammalian pathogens were exhibited to detect the efficacy level of rep-PCR technique $(37,38)$. These techniques were also used to differentiate pathovars and strains of plant-pathogenic Xanthomonads and Pseudomonads (39). Oligonucleotide primers for the amplification of DNA from three families of irrelevant repetitive DNA sequences corresponding to REP (repetitive extragenic palindromic) (40) are required for build this technique, ERIC (enterobacterial repetitive intergenic consensus) (41) and elements of BOX (42). The reasons to use the sequences of REP, ERIC and BOX are to know the evolution of lineages of $X$. oryzae pv. oryzae. In this study, eight pathotypes of $X$. oryzae pv. oryzae were used to analyze the haplotypic variation using RFLP and rep-PCR (REP, ERIC) and BOX.

\section{Materials and Methods}

Isolation and identification of $\mathrm{X}$. oryzae $\mathrm{pv}$. oryzae isolates

Rice leaf samples infected with BB (Bacterial Blight) were coalesced from diverse rice fields, plots and farmers' plantings representing 30 Agro-ecological Zones (AEZs) in Bangladesh, during 2015-2016. From those infected samples, 239 isolates of $X$. oryzae pv. oryzae were isolated by following method described earlier by (23) and each isolates comprised of three replicates. In net house, a pathogenicity test by using a check cultivar IR24 which is susceptible was used to confirm the isolates of $X$. oryzae pv. oryzae. Wizard ${ }^{\circledR}$ genomic DNA purification kit (Promega, Madison, WI, USA) was used for the extraction of the genomic DNA of $X$. oryzae pv. oryzae. By using this kit genomic DNA was extracted from $1 \mathrm{ml}$ of liquid culture of each isolate. Extraction of genomic DNA from each strain of $X$. oryzae pv. oryzae were quantified using a UV spectrophotometer absorbance at $260 \mathrm{~nm}$ with a model T-80 UV/VIS and stored at $-20^{\circ} \mathrm{C} \mathrm{(23).}$ Genomic DNA was stored at $-20{ }^{\circ} \mathrm{C}$. DNA concentration were adjusted to $100 \mathrm{ng} / \mu \mathrm{l}$ and verified for PCR on $1.5 \%$ agarose gel. Very specific primers XOR-F (GCATGACGTCA
TCGTCCTGT) and XOR-R2 (CTCGGAGCTATATGCCGTGC) and XOR-F (GCATGACGTCATCGTCCTGT) were also utilised for the confirmation of $X$. oryzae pv. oryzae has documented earlier (43) with the help of GoTaq ${ }^{\circ}$ G2 Green Master Mix (Promega, Madison, WI, USA). PCR conditions were maintained by sequentially as follows: 2 min initial denaturation at $95{ }^{\circ} \mathrm{C}, 30 \mathrm{sec}$ initial denaturation with 30 cycles at $95{ }^{\circ} \mathrm{C}$, $30 \mathrm{sec}$ annealing at $63^{\circ} \mathrm{C}, 1 \mathrm{~min}$ extension at $72^{\circ} \mathrm{C}$ and finally 7 min extension at $72^{\circ} \mathrm{C}$. The molecular size marker was a 100-bp DNA ladder (Invitrogen).

\section{Pathotype analysis}

A method described (23) that ten (10) near-isogenic lines (NILs) of rice those were IRBB2, IRBB4, IRBB1, IRBB5, IRBB8, IRBB13, IRBB14, IRBB21, IRBB11 and IRBB10 carrying a BB $R$ -gene in the background of IR24 (a susceptible check cultivar) gone through a pathotypic analyses of the pathogen of BB.

\section{RFLP analysis using avrBs3 repeat domain as probe}

The genetic diversity of the pathogen of BB pathotypes were assessed using RFLP analyses with avrBs3 repeat region as probe as described previously by (44) with some modifications using Alkphos direct labelling kit (GE Healthcare/Amersham) where two replicates were used for each pathotypes. Genomic DNA ( $5 \mu \mathrm{g}$ ) of each pathotype of $X$. oryzae pv. oryzae was digested with $2 \mu \mathrm{l}$ of EcoRI (Invitrogen) in a reaction volume $20 \mu \mathrm{l}$ containing $1 \mu \mathrm{l}$ of RNAse $A(10 \mathrm{mg} / \mathrm{ml})$ at $37{ }^{\circ} \mathrm{C}$ for at least $8 \mathrm{hrs}$ and the digested DNA was then separated on $0.7 \%$ agarose gel for overnight (18 hrs) at 40V. The DNA was then transferred to Hybond N+-membrane by capillary action for overnight and was fixed by exposing the membrane under UV light for 5 min. Probe was prepared by PCR amplification of the avrBs 3 repeat domain containing the $2.0 \mathrm{~kb}$ fragment using primers AvrBs3-FP: 5' -AGACGGTGCAGCGGCTGTT-3', AvrBs3-RP: 5'TGGGATGGCCACGACCTGGT-3' with PCR conditions: 2 min initial denaturation at $95^{\circ} \mathrm{C}, 30 \mathrm{sec}$ initial denaturation with 30 cycles at $95^{\circ} \mathrm{C}, 30 \mathrm{sec}$ annealing at $63^{\circ} \mathrm{C}, 1 \mathrm{~min}$ extension at $72^{\circ} \mathrm{C}$ and finally $7 \mathrm{~min}$ extension at $72{ }^{\circ} \mathrm{C}$. The PCR products were confirmed by sequencing according to the standard protocols for the ABI 3730xl DNA genetic analyzer (Applied Biosystems, Foster City, CA, USA) with BigDye ${ }^{\circledR}$ Terminator v1.1 and 3.1 Cycle Sequencing Kits. The probe was then labelled with Alkphos direct labelling kit (GE Healthcare/Amersham) according to manufacturer's instruction, Pre-hybridization, hybridization and post-hybridization washes were performed according the manufacturer's instruction.

\section{Identification of avirulence genes from X. oryzae pv. ory-} zae

In order to confirm the presence of the known avrBs3 family members, phenotypic characterization was performed by assessing the avirulence and aggressiveness of $X$. oryzae pv. oryzae pathotypes or races on rice NILs containing $R$ genes (Xa7 and Xa10) and IR-24 was used as control (45). The virulence assays were performed by leaf infiltration method according to $(46,47)$. Briefly, bacterial suspensions were inoculated to rice leaves of 16 days old rice seedlings by infiltration of bacterial suspension $\left(5 \times 10^{7} \mathrm{CFU} / \mathrm{ml}\right)$ with hypodermal syringe after pricking the leaves with insect pin 
(47). By the method of infiltration the development of symptoms were analysed after inoculation at least 5 days later. 2, 4 and 5 days after infiltration lesion lengths were scored after leaf-clip inoculation because incompatible responses involving $X a 7$ and $X a 10$ take longer to develop than those involving Xa7 (3-4days) and Xa10 (4-5 days).

\section{Rep-PCR analysis of $X$. oryzae $p v$. oryzae}

Molecular haplotyping of $X$. oryzae pv. oryzae pathotypes was carried out by rep-PCR. Rep-PCR analyses of $X$. oryzae pv. oryzae pathotypes were performed as described previously (34). For the process of rep-PCR primers were as follows: for ERIC, ERIC (5'-ATGTAAGCTCCTGGGGATTCAC-3' and ERIC2 (5'-AAGAAGTGACTGG GGTGAGCG-3'), for REP, REP (5'-CGICGICATCIGGC-3') and REP2-1 (5'ICGICITATCIGGCCTAC-3') and for BOX, BOX (5'-CTACGGCAA GGCGA CGCTGACG-3'). The conditions for PCR amplification were: for the REP primers, the cycles were as follows: 6 min for 1 cycle at $95^{\circ} \mathrm{C}, 1 \mathrm{~min}$ for 30 cycles at 94 ${ }^{\circ} \mathrm{C}, 1 \mathrm{~min}$ at $40{ }^{\circ} \mathrm{C}$, and $8 \mathrm{~min}$ at $65^{\circ} \mathrm{C}$; $16 \mathrm{~min}$ for 1 cycle at $65{ }^{\circ} \mathrm{C}$; For the ERIC primers, 7 min for the first cycle at $95{ }^{\circ} \mathrm{C}$ followed by at $94{ }^{\circ} \mathrm{C} 30$ cycles for $1 \mathrm{~min}, 1 \mathrm{~min}$ at 52 ${ }^{\circ} \mathrm{C}$, and $8 \mathrm{~min}$ at $65^{\circ} \mathrm{C} ; 16 \mathrm{~min}$ for 1 cycle at $65^{\circ} \mathrm{C}$ (39) and for the BOX primers, $7 \mathrm{~min}$ for the first cycle at $95^{\circ} \mathrm{C}$ followed by $1 \mathrm{~min}$ for 30 cycles at $94^{\circ} \mathrm{C}, 1 \mathrm{~min}$ at $53^{\circ} \mathrm{C}$, and $8 \mathrm{~min}$ at $65^{\circ} \mathrm{C}$; $16 \mathrm{~min}$ for $1 \mathrm{cycle}$ at $65^{\circ} \mathrm{C}$; and at $4{ }^{\circ} \mathrm{C}$ for the final soak (48). Temperature for each PCR conditions were varied due to having different melting temperatures of forward and reverse primers of REP, ERIC and BOX. Template DNA (50 ng) was used per reaction. 1.5\% agarose in 1XTBE buffer (Tris base, boric acid and $0.5 \mathrm{M}$ EDTA [pH 8.0]) was used for the analysis of PCR products using $0.5 \mu \mathrm{g} / \mathrm{ml}$ ethidium bromide. After electrophoresis, the gel was placed under UV transilluminator (GelView Master, Dynamica, UK) for visualization of DNA bands.

\section{Data analysis}

An unweighted pair group method of averages (UPGMA) was used for making dendograms belong to SAHN programme of NTSYSpc 2.02i (Exeter Software, Setauket, NY) and a dice coefficient option was exploited from making similarity matrix as well as by using Winboot (a computer program) was directed to assess the dendrogram robustness. To detect the confidence limits of each dendrogram 1000 replications of bootstrap analysis were employed by the exact computer program.

\section{Results}

\section{Confirmation of $X$. oryzae pv. oryzae by PCR}

$X$. oryzae pv. oryzae isolates were confirmed by PCR amplification of genomic DNA of the 8 representative pathotypes (I-VIII) and negative control was maintained with nuclease-free water. Results showed that the primers XOR-F and XOR-R amplified a specific DNA fragment in the size of 470-bp with DNA of all $X$. oryzae pv. oryzae pathotypes (Fig. 1).

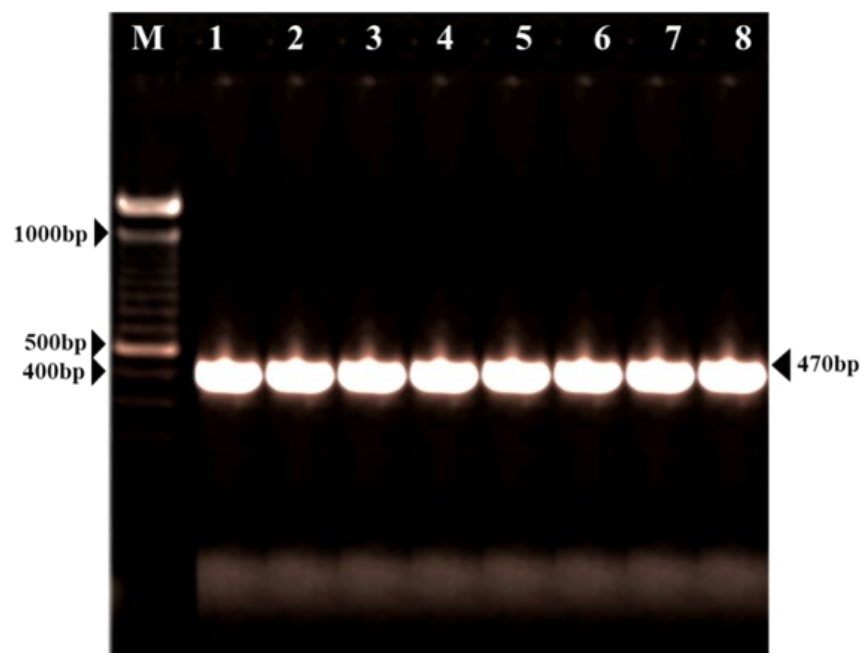

Fig. 1. PCR confirmation of $X$. oryzae pv. oryzae isolates representing eight pathotypes using primer XOR-F and XOR-R. M: the molecular size marker is a 100-bp DNA ladder.

\section{Determination of pathotypes of $X$. oryzae pv. oryzae field} isolates

239 X. oryzae pv. oryzae pathotypes of field isolates were determined depend on their reactions against ten Near Isogenic Lines (NILs) and a total eight pathotypes (I-VIII) were determined. Pathotype IV consisted of maximum 72 isolates followed by Pathotype V- 55, Pathotype III- 36, Pathotype II- 28, Pathotype I- 17, Pathotype VI- 13, Pathotype VII12 and Pathotype VIII- 6. Pathotype I showed the uppermost virulence congenial with all NILs, conversely, pathotype VIII manifested minimum virulence inharmonious with NILs. Except Xa1, Xa4 and Xa5, pathotype VIII manifested avirulence reactions against all $R$-genes. Pathotype II performed better virulence by showing maximum compatible reaction to NILs. Pathotype II showed avirulence reaction only with Xa1, Xa8 and Xa21. Pathotype III performed avirulence interactions to four $R$-genes and showed virulence responses to $\mathrm{Xa4}, \mathrm{Xa5}, \mathrm{Xa8}, \mathrm{Xa13}, \mathrm{Xa14}$ and $\mathrm{Xa21}$. The major pathotype IV exposed virulence response to $X a 2, X a 4, X a 8$, $X a 10, X a 14$ and $X a 21$ whereas pathotype $\mathrm{V}$ exhibited virulence reactions to $X a 2, X a 5, X a 8, X a 13$ and $X a 14$. Pathotype $\mathrm{VI}$ exhibited virulence response to $\mathrm{Xa2}, \mathrm{Xa4}, \mathrm{Xa5}, \mathrm{Xa11}$ and xa13 whereas pathotype VII exposed virulence reactions with $\mathrm{Xa4}$, Xa10, Xa13 and Xa14. Likewise, virulence and avirulence reactions was found in all other pathotype to each other with NILs tested (Table 1).

\section{RFLP analysis}

RFLP based genotyping of eight pathotypes of $X$. oryzae pv. oryzae was performed by southern hybridization using avrBs3 repeat region as DNA fingerprinting probe to determine their genetic relationship. The results conceded that two to nine fragments were detected after hybridization of ECOR1 genomic DNA fragments of these eight pathotypes of $X$. oryzae pv. oryzae with molecular weight approximately $500 \mathrm{bp}$ to $13 \mathrm{~kb}$ (Fig. 2). This result indicated that the isolates representing each pathotype encoded multiple avrBs3 homologs. Among the isolates representing eight pathotypes, $X$. oryzae pv. oryzae isolates representing pathotype I generated only two bands and the isolates representing pathotypes I and VII generated highest number (nine) of 
Table 1. Response of NILs to eight pathotypes of X. oryzae pv. oryzae isolates in irrigated and rainfed season during 2016

\begin{tabular}{|c|c|c|c|c|c|c|c|c|c|c|c|c|c|}
\hline \multirow[b]{2}{*}{ Pathotype } & \multirow[b]{2}{*}{ Total Isolates } & \multirow[b]{2}{*}{$\%$ of Isolates } & \multicolumn{11}{|c|}{ Near-Isogenic Lines (NILs) and single known resistance genes ${ }^{a}$} \\
\hline & & & $\begin{array}{r}\text { IRBB1 } \\
(X a 1)\end{array}$ & $\begin{array}{l}\text { IRBB2 } \\
(X a 2)\end{array}$ & $\begin{array}{r}\text { IRBB4 } \\
(X a 4)\end{array}$ & $\begin{array}{c}\text { IRBB5 } \\
\text { (xa5) }\end{array}$ & $\begin{array}{l}\text { IRBB8 } \\
(X a 8)\end{array}$ & $\begin{array}{l}\text { IRBB10 } \\
\text { (Xa10) }\end{array}$ & $\begin{array}{l}\text { IRBB11 } \\
\text { (Xa11) }\end{array}$ & $\begin{array}{c}\text { IRBB13 } \\
\text { (xa13) }\end{array}$ & $\begin{array}{c}\text { IRBB14 } \\
\text { (Xa14) }\end{array}$ & $\begin{array}{l}\text { IRBB21 } \\
(X a 21)\end{array}$ & $\begin{array}{c}\text { IR24 } \\
\text { (susceptible) }\end{array}$ \\
\hline I & 17 & 7.11 & $S^{b}$ & $\mathrm{~S}$ & $\mathrm{~S}$ & $\mathrm{~S}$ & $\mathrm{~S}$ & S & $\mathrm{S}$ & $\mathrm{S}$ & $\mathrm{S}$ & $\mathrm{S}$ & $\mathrm{S}$ \\
\hline II & 28 & 11.72 & $\mathrm{R}$ & $\mathrm{S}$ & $\mathrm{S}$ & $\mathrm{S}$ & $\mathrm{R}$ & $\mathrm{S}$ & $\mathrm{S}$ & $\mathrm{S}$ & $\mathrm{S}$ & $\mathrm{R}$ & $\mathrm{S}$ \\
\hline III & 36 & 15.06 & $\mathrm{R}$ & $\mathrm{R}$ & $S$ & $\mathrm{~S}$ & $S$ & $\mathrm{R}$ & $\mathrm{R}$ & $S$ & $S$ & $S$ & $S$ \\
\hline IV & 72 & 30.13 & $\mathrm{R}$ & $S$ & $S$ & $\mathrm{R}$ & $S$ & $S$ & $\mathrm{R}$ & $\mathrm{R}$ & $S$ & $S$ & $S$ \\
\hline V & 55 & 23.01 & $\mathrm{R}$ & $S$ & $\mathrm{R}$ & $S$ & $S$ & $\mathrm{R}$ & $\mathrm{R}$ & $S$ & $S$ & $\mathrm{R}$ & $S$ \\
\hline VI & 13 & 5.44 & $\mathrm{R}$ & $S$ & $S$ & $S$ & $\mathrm{R}$ & $\mathrm{R}$ & $S$ & $S$ & $\mathrm{R}$ & $\mathrm{R}$ & $S$ \\
\hline VII & 12 & 5.02 & $\mathrm{R}$ & $\mathrm{R}$ & $S$ & $\mathrm{R}$ & $\mathrm{R}$ & $S$ & $\mathrm{R}$ & $S$ & $S$ & $\mathrm{R}$ & $S$ \\
\hline VIII & 6 & 2.51 & $S$ & $\mathrm{R}$ & $S$ & $S$ & $\mathrm{R}$ & $\mathrm{R}$ & $\mathrm{R}$ & $\mathrm{R}$ & $\mathrm{R}$ & $\mathrm{R}$ & $S$ \\
\hline
\end{tabular}

aRBB 7 and IRBB10 contain the $X a-7$ and $X a-10$ genes, respectively and susceptible check IR 24 .

${ }^{\mathrm{b}} \mathrm{R}$ indicates the infiltration site turns brown, characteristics of an incompatible interaction.

${ }^{\mathrm{C}} \mathrm{S}$ indicates the infiltration site is water soaked, characteristics of an compatible interaction.
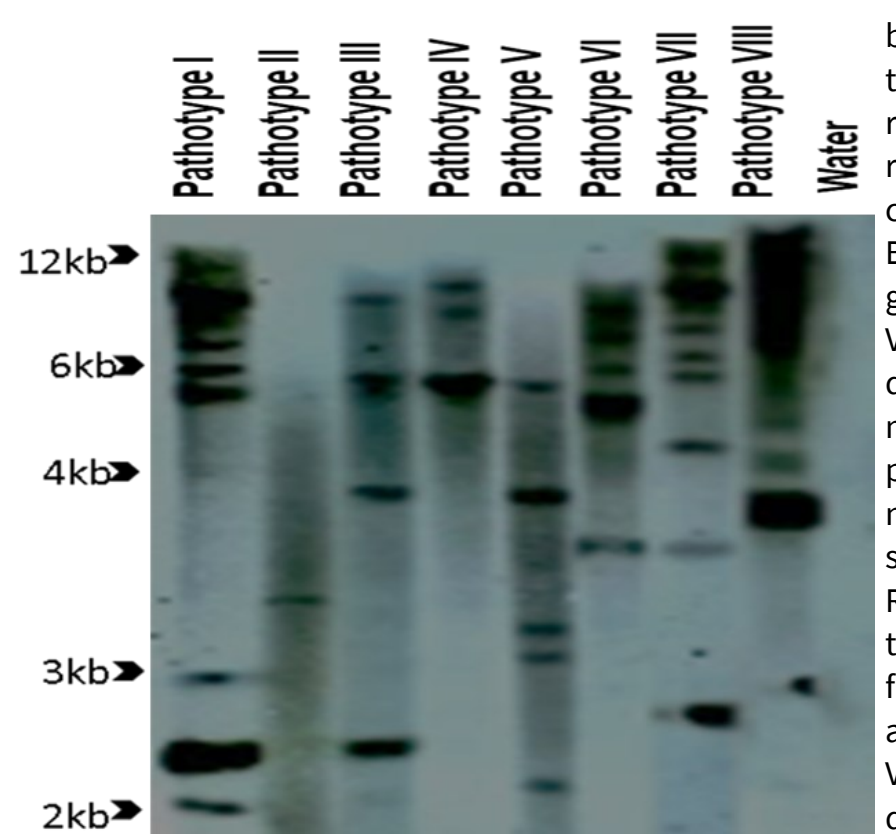

Fig. 2. RFLP (Restriction Fragment Length Polymorphism) analysis of $X$. oryzae pv. oryzae pathotypes using avrBs3 repeat region as probe. Genomic DNA was isolated from eight $X$. oryzae pv. oryzae pathotypes and southern blot hybridization was performed using the avrBs 3 probe as described in Methodology. Four different RFLP clades of $X$. oryzae pv. oryzae isolates representing eight pathotypes were identified. M: a 1 kb DNA ladder (Invitrogen) was added as a size marker. Lanes 1-8 represent the DNAs obtained from $X$. oryzae pv. oryzae isolates of representing pathotypes, lane 9: W-water.

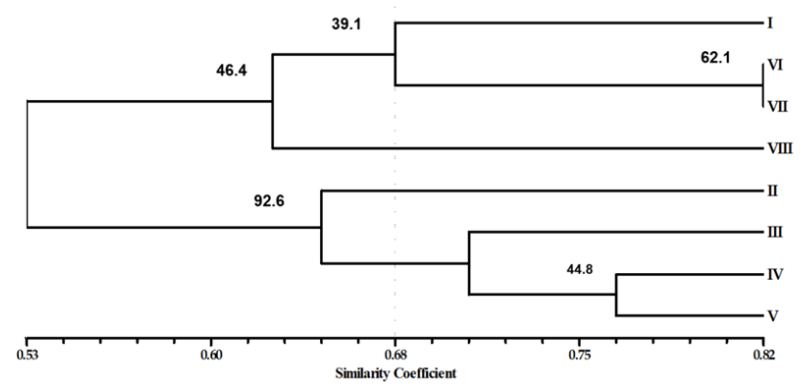

Fig. 3. Dendrogram illustrating the genetic relationship among eight pathotypes of $X$. oryzaepv. oryzae based on RFLP data by UPGMA clustering. A data matrix was generated for the presence of band as 1 and absence of band as 0 for the construction of dendrogram. A similarity matrix was derived with the SIMQUAL program (NTSYSpc, version 2.02i, Exeter Biological Software, Setauket, NY) using Jaccard's coefficient of similarity bands. The UPGMA cluster analysis was shown in Fig. 3 obtaining from Jaccard similarity coefficients. Phylogenetic relationship revealed that $X$. oryzae pv. oryzae isolates representing eight pathotypes distributed into four RFLP clades and these clades are widely distributed all over Bangladesh as depicted in the dendrogram at $68 \%$ homology. Clade I contained 42 strains belonging to pathotypes I, $\mathrm{VI}, \mathrm{VII}$ and these isolates were obtained from 3 different districts viz. Bogura (AEZ 4), Sylhet (AEZ 20) and Lakshmipur (AEZ 17), Clade II contained 6 strains belonging to pathotype VIII which were isolated from 2 districts viz. Khulna (AEZ 13) and Barishal (AEZ13), Clade III contained 28 strains belonging to pathotype II isolated from the districts Rangpur (AEZ 27) and Dinajpur (AEZ 1) and Clade IV contained 163 strains belonging to pathotype III, IV, V obtained from the districts Rajshahi (AEZ 26), Panchagarh (AEZ 1) and Mymensingh (AEZ 8). This depicts that pathotypes I, VI, VII comprised of genetically nearly related isolates from diverse locations and pathotypes III, IV and V composed of isolates from several widely distributed locations in Bangladesh.

Identification of avirulence gene from $X_{0}$ oryzae pv. oryzae

To confirm the presence of any known avrBs3 homolog in representative $X$. oryzae pv. oryzae isolates, isolates of each pathotype were undergone a pathogenicity test on rice lines IRBBXa7 and IRBBXa10 containing Xa7 and Xa10 Rgenes respectively. The reactions of the phenotypes fluctuated with involving resistance genes $(X a 1, X a 2, X a 4, X a 5$, $X a 8, X a 10, X a 11, X a 13, X a 14, X a 21)$ in the interaction between $X$. oryzae pv. oryzae pathotypes and the rice lines IRBB. Within 24-48 hrs a dark brown colour is formed all the area of infiltrated site when an interaction happened between rice line $X a 10$ and $X$. oryzae pv. oryzae pathotypes, on the other hand, at 48 hrs a dark margin colour formed around the perimeter of the water-soaked area containing rice line with $\mathrm{Xa} 7$ as well as tan to brown colour formed in tissue locating within the site at $72 \mathrm{hrs}$ (Table 2). In the infiltration site congenial interactions in too combinations stayed water-soaked through at 5 days, after that time the leaf had gone wilting and the water-soaked lesion had resulted into spreading. The resistance phenotype character- 
Table 2. Interactions of $X$. oryzae pv. oryzae strains with near-isogenic rice cultivar

\begin{tabular}{lccc}
\hline \multirow{2}{*}{ Pathotypes } & \multicolumn{3}{c}{ Rice cultivar $^{\mathbf{a}}$} \\
\cline { 2 - 4 } & IRBB7 & IRBB10 & IR24 \\
\hline I (BDX091) & $\mathrm{R}^{\mathrm{b}}$ & $\mathrm{R}$ & $\mathrm{S}$ \\
II (BDX068) & $\mathrm{S}^{\mathrm{C}}$ & $\mathrm{S}$ & $\mathrm{S}$ \\
III (BDX098) & $\mathrm{R}$ & $\mathrm{S}$ & $\mathrm{S}$ \\
IV (BDX034) & $\mathrm{R}$ & $\mathrm{S}$ & $\mathrm{S}$ \\
V (BDXOS6) & $\mathrm{R}$ & $\mathrm{R}$ & $\mathrm{S}$ \\
VI (BDX0210) & $\mathrm{S}$ & $\mathrm{S}$ & $\mathrm{S}$ \\
VII (BDX0251) & $\mathrm{S}$ & $\mathrm{S}$ & $\mathrm{S}$ \\
VIII (BDX0319) & $\mathrm{S}$ & $\mathrm{R}$ & $\mathrm{S}$ \\
\hline
\end{tabular}

aIRBB7 and IRBB10 contain the $X a-7$ and $X a-10$ genes respectively and susceptible check IR24.

${ }^{\mathrm{b}} \mathrm{R}$ indicates the infiltration site turns brown, characteristics of an incompatible interaction.

c $\mathrm{S}$ indicates the infiltration site is watersoaked, characteristics of an compatible interaction.

ized by turning brown of the infiltration site that was observed after inoculation of 16 days old rice seedlings in case of pathotype I (BDX091), pathotype III, Pathotype IV and Pathotype V (BDXOS6) on IRBB7 and suggesting the pathotypes containing avrXa7 gene. On the other hand, resistance phenotype that was noticed in case of pathotypes I (BDX091), V (BDXOS6) and pathotype VIII (BDXO319) on IRBB10 line conceded that these pathotypes containing avrXa10 (Fig. 4).
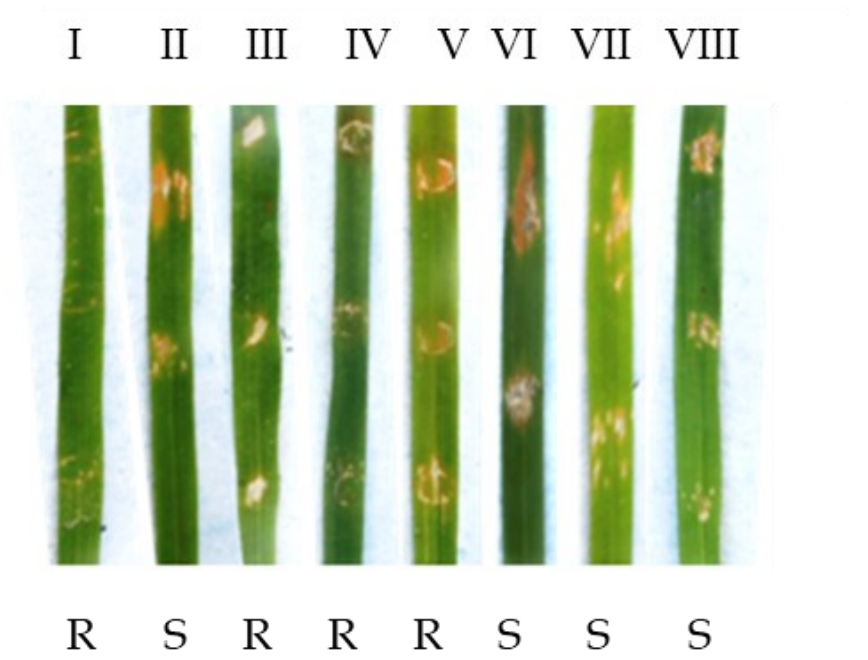

150-3000 bp in case of ERIC and 400-2500 bp in case of BOX primers. Dendrogram constructed based on the REP primer from the pooled data had three main clades. Clade I consisted of isolates of pathotypes I (BDX091), II (BDXO68) and VIII (BDXO319) obtained from the districts Bogura (AEZ 4), Rangpur (AEZ 27) and Barishal (AEZ 13). Clade II formed by pathotypes III (BDX098), pathotypes IV (BDXO34) and pathotypes $\mathrm{V}$ (BDXOS6) belong to the districts Tangail (AEZ9), Thakurgaon (AEZ1), Panchagarh (AEZ1) respectively. The Clade III contained pathotypes VI (BDXO210) and pathotypes VII (BDXO251), all these isolates belonged to Natore (AEZ5), Habiganj (AEZ22), Feni (AEZ19), Lakshmipur (AEZ17) and Bhola (AEZ13). The similarity among strains among these Clades varied at around 60\% (Fig. 6A). The dendrogram constructed based on ERIC from the pooled data had three main clades. Clade I consisted of isolates of pathotypes I obtained from the district Bogura (AEZ 4). Clade II formed by pathotypes II, pathotypes VII and pathotypes VIII belongs to Rangpur (AEZ 27), Habiganj (AEZ 22) and Barishal (AEZ 13). The Clade III contained pathotypes III, IV, V and VI under the districts Tangail (AEZ 9), Thakurgaon (AEZ 1), Panchagarh (AEZ 1) and Natore (AEZ 5). The similarity among strains among these clades varied at around $60 \%$ (Fig. 6B). Dendrogram constructed based on BOX primer from the pooled data had two clades. Clade I consisted isolates of pathotypes I, VIII and V. Clade II was represented by $X$. oryzae pv. oryzae isolates of pathotypes II, III, IV, VI and VII collected from Rangpur (AEZ 27), Natore (AEZ 5), Panchagarh (AEZ 1), Netrokona (AEZ 9), Habiganj (AEZ 22), and Lakshmipur (AEZ 18) districts. The similarity among

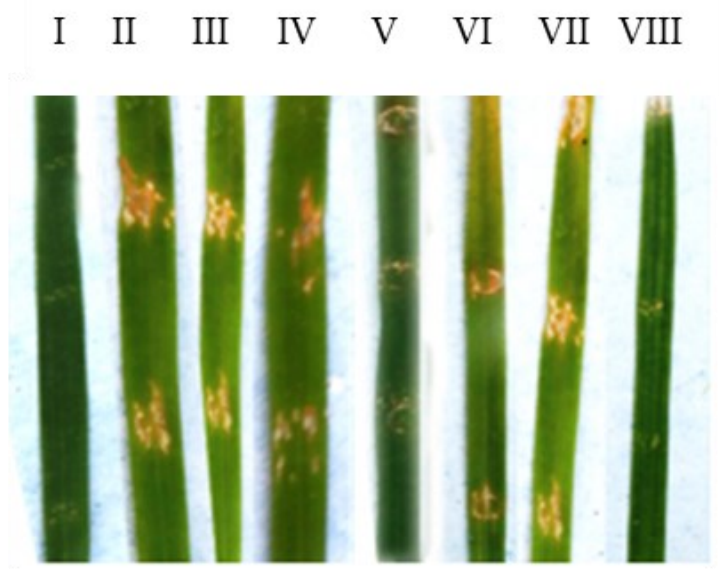

$\begin{array}{llllllll}\mathrm{R} & \mathrm{S} & \mathrm{R} & \mathrm{R} & \mathrm{R} & \mathrm{S} & \mathrm{S} & \mathrm{S}\end{array}$

Fig. 4. Virulence (S) and avirulence (R) activity of different pathotypes on IRBB7 (A) and IRBB10 (B) containing Xa7 and Xa10R genes, respectively. $R$ indicates the infiltration.

\section{Rep-PCR analysis}

The genetic relationships among $X$. oryzae pv. oryzae isolates collected from 30 rice growing AEZs in Bangladesh representing eight pathotypes were determined by analysing banding patterns of rep-PCR (Fig. 5). Rep-PCR (REP, ERIC) and BOX primers produced a total of 13,18 and 10 bands respectively of which all bands (100\%) were considered as polymorphic respectively. Among the pairing site of the DNA strand and the primer of low homology perhaps showed delicate bands. Amplification products size ranged from approximately 400-3000 bp (base pair) in case of REP, strains between these sub-clusters varied at around 68\% (Fig. 6C). However, dendrogram constructed based on repPCR (REP, ERIC, and BOX) from the pooled data had two clades. Clade I consisted isolates of pathotypes I and Clade II was represented by $X$. oryzae pv. oryzae isolates of pathotypes II, III, IV, V, VI, VII and VIII. The similarity among strains between these sub-clusters varied at around 70\% (Fig. 6D).

Comparison of RFLP and rep-PCR analyses on field isolates

RFLP with the avrBs3 probe and rep-PCR with the ERIC and REP Primers were used to detect the level of diversity of $X$. 


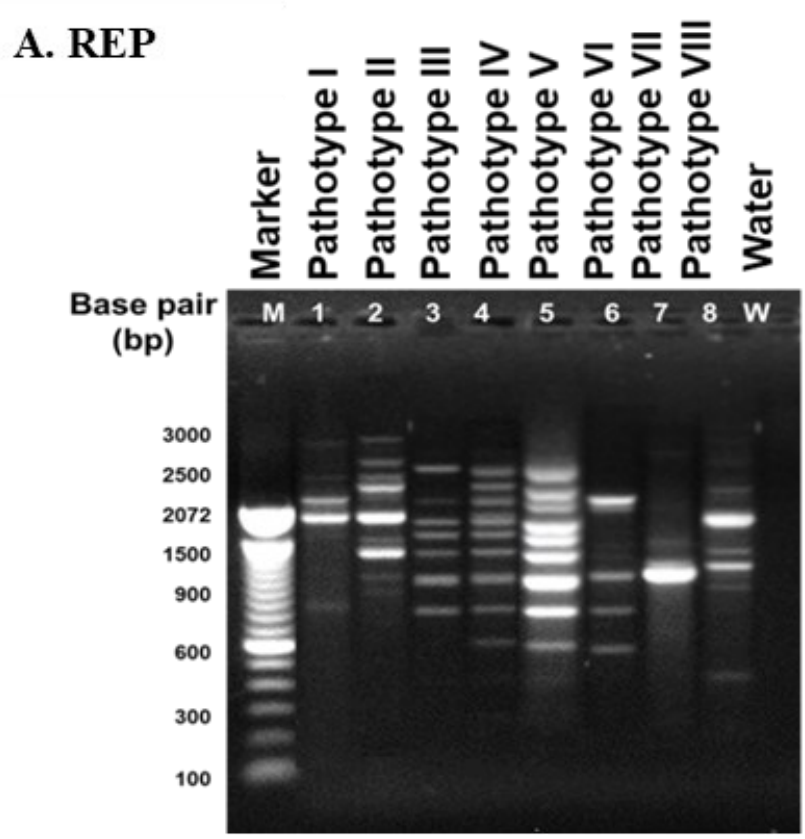

\section{B.ERIC}

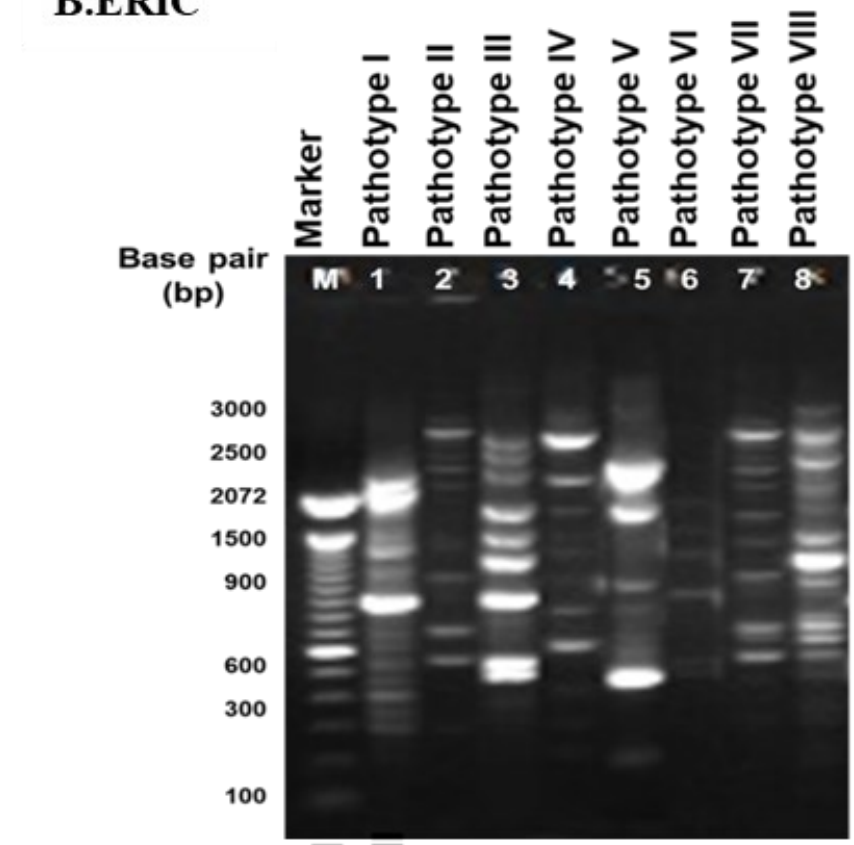

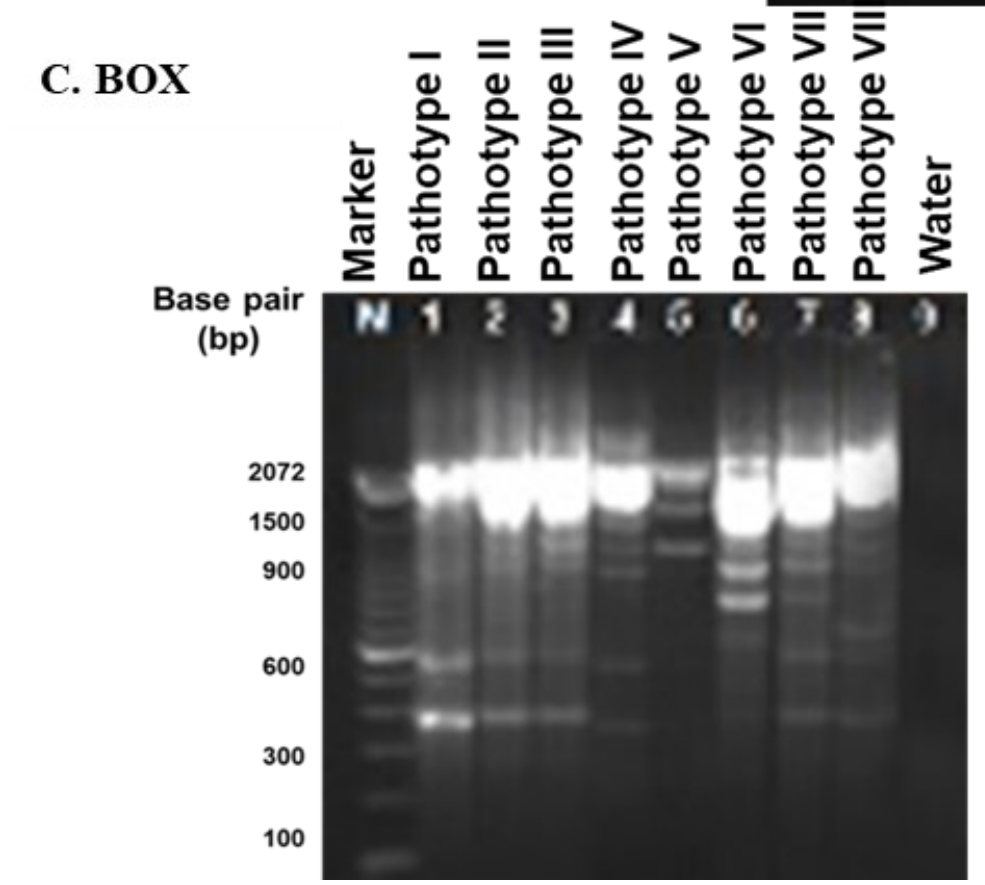

Fig. 5. Agarose gel showing representative banding patterns of each pathotypes of $X$. oryzae pv. oryzae generated by repetitive sequence-based polymerase chain reaction (rep-PCR) with repetitive extragenic palindromic (REP, ERIC and BOX) Primers. After amplification by PCR, the DNA fragments were separated in agarose gels and visualized by staining with ethidium bromide. Molecular weight marker M: 100 bp DNA Ladder (Invitrogen). Numbers to the left indicate molecular weight in base pairs. lane 1-8: X. oryzae pv. oryzae pathotypes and lane 9: Water (control).

oryzae pv. oryzae isolates from field. The 239 isolates of BB lineages possess same pathotype. Bootstrap values (100\% pathogen distributed in eight pathotypes and were distinct- for each lineage) indicated highly reliable groups.

ly separated into two lineages, with only $62 \%$ similarity in RFLP analysis (Fig. 7A) and with $76 \%$ similarity in rep-PCR (Fig. 7B). The two lineages discerned by rep-PCR contained the different isolates as the lineages defined by RFLP analy- $A$ sis. Lineage $A$ was separated into three haplotypes (designated pathotypes I, VI, VII and VIII) whereas B as detected by RFLP with avrBs3 separated into three haplotypes composed of pathotypes II, III, IV \& V. In the combined repPCR and RFLP data analyses of field populations of $X$. oryzae pv. oryzae characterise two lineages, A contains isolates of pathotype I and B contains isolates of pathotypes II, III, IV, VII, VIII, V and VI (Fig. 7C). The results indicated the same pathotypes distributed in different lineages and different
Correlation between pathotypes and molecular haplotypes of Xoo in Bangladesh

A phenogram was structure depending on the virulence of isolates (X. oryzae pv. oryzae) to the ten (NILs) Near Isogenic Lines of rice carrying single $R$-gene to elucidate the relationship between haplotypes and the pathotypes (Fig. 8). Constructed based on the outcomes of inoculation in the phenogram where four haplotypes were exploited at $63 \%$ level of similarity. From all of these haplotypes, haplotypes II considered as most important which comprises number of pathotypes III, V containing 91 isolates out of 239. Haplotype I contained number of isolates (89) belongs to patho- 


\section{A. REP PCR}
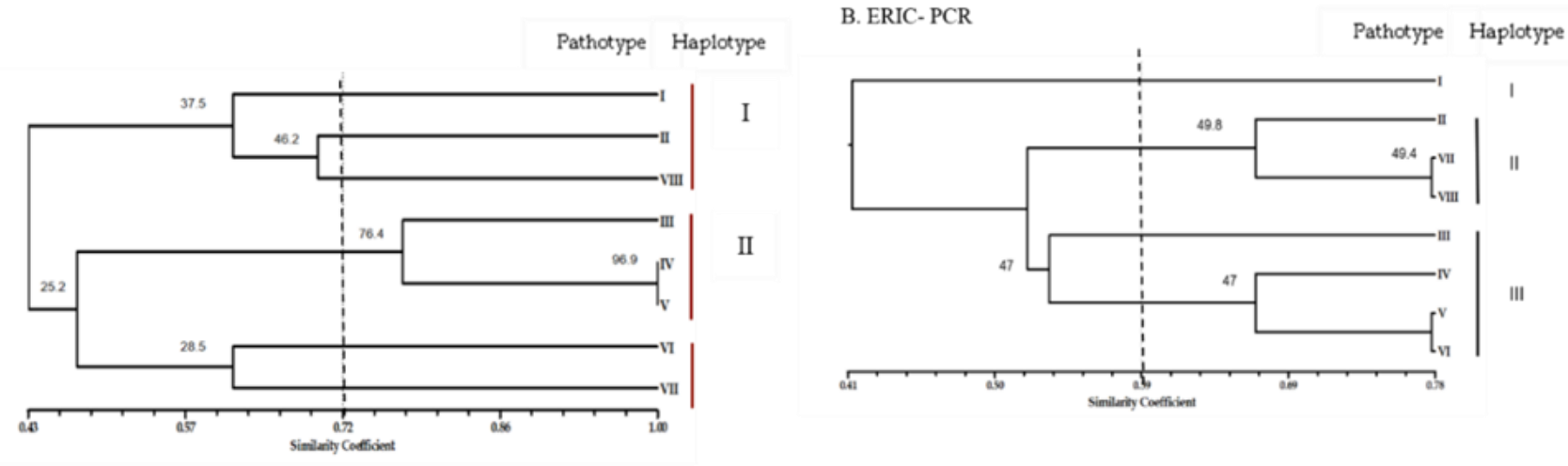

D. Combined (rep-PCR)
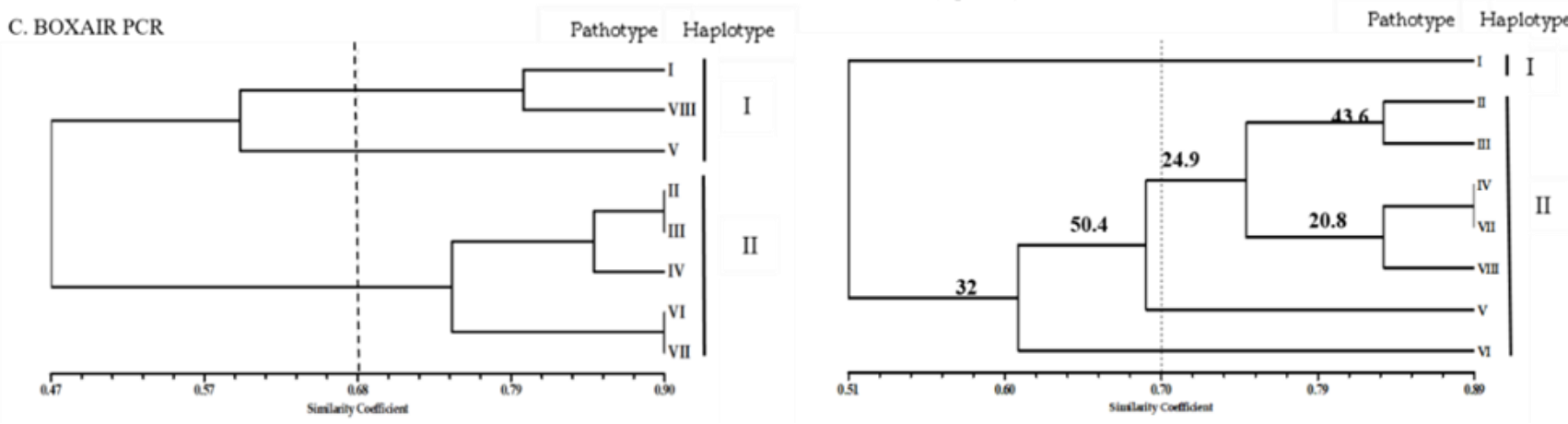

Fig. 6. Dendrograms illustrating the genetic relationship among eight pathotypes of $X$. oryzae pv. oryzae based on REP (A), ERIC (B) and BOX (C)RFLP data by UPGMA clustering. A data matrix was generated for the presence of band as 1 and absence of band as 0 for the construction of dendrogram. A similarity matrix was derived with the SIMQUAL program (NTSYSpc, version 2.02i, Exeter Biological Software, Setauket, NY) using Jaccard's coefficient of similarity. A. REP; B. ERIC; C. BOX elements; D. Combined Repetitive sequence-based polymerase chain reaction (rep-PCR) analyses of $X$. oryzae pv. oryzae pathotypes distinguished two haplotypes, Similarity between pairs of strains was determined by Jaccard's method, and clusters were generated by the UPGMA by NTSYS-pc. The numbers at the base of each node are bootstrap values analyzed by the program Winboot that represent statistical reliability of the nodes.

Pathotype Lineage

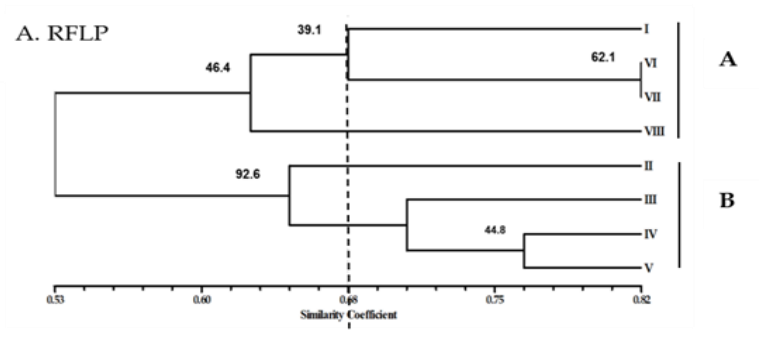

B. Rep-PCR

Pathotype lineage
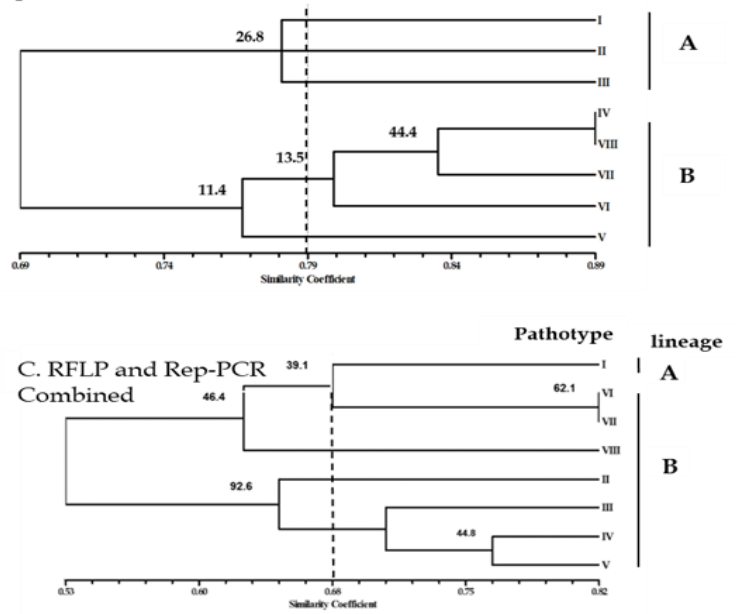

Fig. 7. Restriction fragment length polymorphism (RFLP) (A), repetitive sequence-based polymerase chain reaction (rep-PCR) (B); and Combined RFLP -rep-PCR analyses (C) of $X$. oryzae pv. oryzae field populations distinguished two lineages, $A$ and $B$. Similarity between pairs of strains was determined by Jaccard's method, and clusters were generated by the UPGMA by NTSYS-pc. The numbers at the base of each node are bootstrap values analyzed by the program Winboot that represent statistical reliability of the nodes. Nomenclature of RFLP derived haplotype is based on [64].

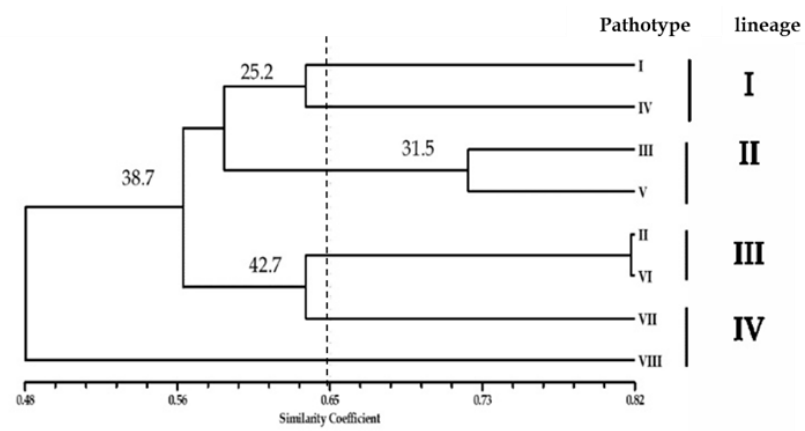

Fig. 8. Phenogram of $X$. oryzae pv. oryzae strains based on virulence to 10 near -isogenic lines containing a single $R$-gene. A data matrix was generated for the virulence data by scoring avirulence as 0 and virulence as 1 . From these data, a similarity matrix was derived with the SIMQUAL program (NTSYSpc, version 2.02i, Exeter Biological Software, Setauket, NY) using Jaccard's coefficient of similarity. A phenogram was reproduced by the unweighted pair group method for arithmetic average in the SAHN Program

types I and IV. Haplotype III comprises 2 pathotypes (II and VI) containing 41 isolates and haplotype IV represented by pathotypes VII, VIII, diverse than other haplotypes. From the phenogram, i) Plentiful haplotypes were exposed from different population with exact pathotypes of the group of isolates of $X$. oryzae pv. oryzae, ii) those diverse populations had same type of haplotypes in a lot of pathotypes and iii) the group of isolates of $X$. oryzae pv. oryzae from multifarious population had the identical haplotypes and pathotypes.

\section{Discussion}

The evolutionary process of an organism includes genetic polymorphisms which are occurred due to numerous phases such as genetic recombination, horizontal gene transfer 
and mutations (4). These genetic processes called polymorphism including genetic drift, gene transfer and selection are added or removed from different populations eventually (49). Thus, pathogens capability of adaption into diverse ambience more or less depend on its genetic polymorphism. For building completely new virulent ability to infect hosts more accurately bacterial genomes need to be a greater level of polymorphism as it is fundamental (50). In the present research, we analysed the variation of genetic processes of $X$. oryzae pv. oryzae pathotypes in Bangladesh using two DNA markers viz. RFLP using avrBs3 repeat domains and rep-PCR. Results obtained from these DNA markers supported that $X$. oryzae pv. oryzae pathotypes showed a substantial genetic variation in their genomes. RFLP results showed that Bangladeshi $X$. oryzae pv. oryzae isolates representing eight pathotypes carrying a minimum of two and maximum of nine avrBs 3 family gene homologs. Phylogenetic relationship exposed that $X$. oryzae pv. oryzae strains dispersed into two haplophytes (RFLP) and these are largely distributed all round Bangladesh. The virulence differentiation of Bangladeshi $X$. oryzae pv. oryzae pathotypes might be due to the copy number of avrBs3 family genes present in the genome. These results agreed with the notion that $X$. oryzae pv. oryzae possess several homologs and possibly a avrBs3 gene family (35). Variable copy number and genomic location of multiple avrXa27, a member of avrBs3 family gene were also reported in the genome of $X$. oryzae pv. oryzae (4). Avirulence genes of $X$. oryzae pv. ory$z a e$ are one of the main virulence determinants in eliciting BB (bacterial blight) on rice. The presence or absecnce of an avirulence gene in the host gives rise to a compitable (resistant) or incompatible (susceptible) reaction as stated in the gene for gene hypothesis (51). The $X$. oryzae pv. oryzae avirulence genes, avrXa7 and avrXa10 are very similar to avrBs 3 and account for the differences in the sizes of the $B a m H I$ fragments con-tained within the genes (avrBs3, 3.3 $\mathrm{kb}$; avrXa7, $4.1 \mathrm{~kb}$; avrXa10, $3.1 \mathrm{~kb}$ ) by the differences in estimated copy numbers of the 102-bp repeat structure (17.5, 25 and 15.5 respectively) (52). To validate our RFLP fingerprinting using avrBs3 repeat domain, the presence of two known avr genes viz. avrXa7 and avrXa10 were determined by pathogenicity test on rice lines containing $X a 7$ and $X a 10$ respectively. The resistance phenotype that was observed in the present study after inoculation of 16 -days-old rice seedlings in case of pathotypes I, pathotypes III, Pathotype IV and Pathotype V on IRBBXa7 and suggesting these pathotypes containing avrXa7 gene on the other hand, resistance phenotype that was noticed in case of pathotypes I, $\mathrm{V}$ and VIII on IRRBB10 line conceded that these pathotypes may contain avrxa10. X. oryzae pv. oryzae race 2 strain was also found avirulent on rice cultivars carrying resistance genes $X a 5, X a 7$ and $X a 10$ (35).

The rep-PCR technique (repetitive sequence PCR) consists of analysing DNA polymorphism of repetitive sequences occurring in the bacterial genome. The distribution of these sequences is unique for each strain which allows the strains to be differentiated. The rep-PCR is based on the fact that outwardly facing oligonucleotide primers complementary to interspersed repetitive sequences will enable the amplification of differently sized DNA fragments consisting of sequences lying between these elements, however, rep-PCR was introduced to differentiate microbes by combining the advantages of DNA amplification with the application of repetitive sequence-based oligonucleotide primers (53). These repetitive bacterial DNA sequences are described as repetitive extragenic palindromic sequence (REP), enterobacterial repetitive intergenic consensus (ERIC) and the BOX element. REP, ERIC and BOX elements are not only restricted to the DNA sequence and hybridization of eubacterial species but also it is also used for phylogenetic analysis and differentiation of diverse bacterial genera (54) including Rhizobium (55), Frankia (56), Staphylococcus (57), Legionella $(46,58)$. In this study, the genetic variation of eight pathotypes of $X$. oryzae pv. oryzae was estimated by using REP, ERIC and BOX primers. The similarity among strains between these haplotypes varied at around $60 \%, 60 \%$ and $68 \%$ respectively. Two molecular haplotypes were identified of $X$. oryzae pv. oryzae isolates representing eight pathotypes at similarity level $70 \%$ based on rep-PCR data (Fig. 6D). It was observed that remarkable genome variability in both clonal and field isolates of $X$. oryzae pv. oryzae by the amplification of REP, ERIC and BOX-AIR primers despite having cultural and morphological similarities of $X$. oryzae pv. oryzae isolates of rice (59). Haplotypic variation of $X$. oryzae pv. oryzae population was also observed by rep-PCR $(34,60)$. Rep-PCR results revealed that among the African and Asian strains of $X$. oryzae pv. oryzae have dissimilarities in their genomic characteristics (61).

The $239 X$. oryzae pv. oryzae strains collected from the field were distinctly separated into two lineages based on combined RFLP and rep-PCR data, lineage A was separated into 3 haplotypes and lineages $B$ was separated into 4 haplotypes. Bootstrap values (100\% for each lineage) indicated highly reliable groups. In RFLP, cluster I was comprised of four pathotypes where pathotypes VI and VII were closely related to each other at $62 \%$ similarity level as well as pathotypes VIII was equally closely related to pathotypes I, VI, VII at $46 \%$ similarity level. Conversely, in case of RepPCR, cluster I consisted of three pathotypes named pathotype I, II, III exhibiting $26 \%$ similarity to each other, thus no significant correlation was found in cluster I between RFLP and Rep-PCR. In RFLP, cluster II was comprised of four pathotypes (II, III, IV, V) in which IV and V were closely related to each other at $44.8 \%$ similarity as well as pathotype II was equally closely related to III, IV, V at 92\% similarity level, on the other hand, in Rep-PCR, cluster II was consisted of five pathotypes (IV, VIII, VII, VI, V) where $44 \%$ similarity was observed between VII and closely related pathotypes IV and VIII, pathotypes V was equally related to all four pathotypes. Above correlation suggested that eight pathotypes were same but they may vary in the same cluster when compared to RFLP and Rep-PCR.

Present study revealed that due to the exchanging of contaminated germplasm and national movement, there might be dispersion of the pathogen $X$. oryzae pv. oryzae which were detected from several regions of Bangladesh. This diversity might explore a number of complications encountered historically to modify several rice cultivars 
which showed resistance to $X$. oryzae pv. oryzae throughout Bangladesh. RFLP and PCR markers were used to evaluate Indonesian and Philippinan strains of $X$. oryzae pv. oryzae (62). Based on their research they found that strains those were predominant from the collection of pathogens of both of those countries having regional movement because of exchanging germplasm and those both strains were found highly matching (63) declared that a number of resistance genes have the ability to trigger the selection of pathogenic races which are new at a rate exact to 1.64 times the surge in individual virulence of the isolates after one crop cycle following selection pressure of resistance host-plant. Depending on the DNA polymorphism with a large degree, a phenogram and a dendrogram was constructed among $X_{0 O}$ strains (239) isolated from variegated geographic regions of Bangladesh.

All strains exhibiting a multifarious relationship between molecular haplotypes and pathotypes which are genetically, geographically and pathogenically variegated. Identical experimental outcomes was depicted by $(15,64-$ 66). They indicated that the relationship between $X$. oryzae pv. oryzae pathotypes and molecular haplotypes were composite. Similar observations were also recorded (67). They reported that some haplotypes were geographically dispersed and most frequent which occurred in diverse geographic populations in Nepal. Taken together, genetic variability of $X$. oryzae pv. oryzae pathotypes might be due to their variation of places or origins where cultivars with diverse $R$-genes cultivated. These $R$-genes might be responsible for evolving new haplotypes and pathotypes of $X$. oryzae pv. oryzae. RFLP analyses using avrBs3 repeat region conceded that Bangladeshi $X$. oryzae pv. oryzae strains carrying avrBs3 family gene homolog which is crucial and one of the important determinants for the development resistant rice varieties through gene pyramiding. However, analyses of whole genome sequences of some selected Bangladeshi $X$. oryzae pv. oryzae strains would clarify the complex genetic relationship between pathotypes and molecular haplotypes.

\section{Conclusion}

Genetic polymorphisms within the genomes of $X$. oryzae pv. oryzae signifies their evolutionary potential during longterm interaction with its hosts. Information related to the presence of $a v r B s 3$ family gene homologs $X$. oryzae pv. oryzae Bangladeshi strains will be useful for breeding to develop BB resistant rice varieties through corresponding $R$ gene pyramiding to each avirulence gene of $X$. oryzae pv. oryzae 7 . pathotype (s) exist in Bangladesh. Identification of the homolog avr genes in the dominant pathotypes of $X$. oryzae 8 . pv. oryzae exist in Bangladesh and their corresponding $R$ genes would be the next steps of the present study.

\section{Acknowledgements}

This research work was financed by International Foundation for Science (IFS) to Md. Rashidul Islam (Grant no.: C5035-1), Plant Bacteriology and Biotechnology Laboratory,
Department of Plant Pathology, Bangladesh Agricultural University, Mymensingh-2202 and Strengthening Research Activities and Sub-Stations Development of BINA project, Bangladesh. The authors would like to acknowledge Bangladesh Rice Research Institute (BRRI) for the NILs and Pyramid lines of rice.

\section{Authors contributions}

MRI: conceptualization, methodology, supervision, and editing; $\mathrm{MMH}$ : investigation, formal analysis, performed the statistical analysis and writing original draft, MMM: edited the manuscript, SB: edited the manuscript, MZA: edited the manuscript, MIH: edited the manuscript. All authors carefully read and authorized the final manuscript.

\section{Compliance with ethical standards}

Conflict of interest: Authors do not have any conflict of interests to declare.

Ethical issues: None.

\section{References}

1. Chisholm ST, Coaker G, Day B, Staskawicz BJ. Host-microbe interactions: shaping the evolution of the plant immune response. Cell. 2006 Feb 24;124(4):803-14. https://doi.org/10.1016/ j.cell.2006.02.008

2. Anderson JP, Gleason CA, Foley RC, Thrall PH, Burdon JB, Singh KB. Plants versus pathogens: an evolutionary arms race. Functional Plant Biology. 2010 May 20;37(6):499-512. https:// doi.org/10.1071/FP09304

3. Dangl JL, Jones JD. Plant pathogens and integrated defence responses to infection. Nature. 2001 Jun;411(6839):826-33. https://doi.org/10.1038/35081161

4. Hu Y, Rolfs A, Bhullar B, Murthy TV, Zhu C, Berger MF, Camargo AA, Kelley F, McCarron S, Jepson D, Richardson A. Approaching a complete repository of sequence-verified protein-encoding clones for Saccharomyces cerevisiae. Genome Research. 2007 Apr 1;17(4):536-43.http://www.genome.org/cgi/doi/10.1101/ gr.6037607

5. Van Sluys MA, Monteiro-Vitorello CB, Camargo LE, Menck CF, Da Silva AC, Ferro JA, Oliveira MC, Setubal JC, Kitajima JP, Simpson AJ. Comparative genomic analysis of plant-associated bacteria. Annual Review of Phytopathology. 2002 Sep;40(1):169-89. https://doi.org/10.1146/annurev.phyto.40.030402.090559

6. Mew TW, Vera Cruz CM, Medalla ES. Changes in race frequency of Xanthomonas oryzae pv. oryzae in response to rice cultivars planted in the Philippines. Plant Disease. 1992;76(10):1029-32. https://doi.org/10.1094/PD-76-1029

7. Ishiyama S. Studies of bacterial leaf blight of rice. Report of the Imperial Agricultural Station. 1992;45:233-61.

Swing JR. Classification of the causal agents of bacterial blight (Xanthomonas campestris pv. oryzae) and bacterial leaf streak (Xanthomonas campestris pv. oryzicola) of rice as pathovars of Xanthomonas oryzae (ex Ishiyama 1922) sp. nov. nom. rev. International Journal of Systematic Bacteriology. 1990;40:309-11. https://doi.org/10.1099/00207713-40-3-309

9. Mew TW, Wu SZ, Horino H. Pathotypes of $X$. campestris pv. oryzae in Asia. IRRI Research Paper Series 75. International Rice Research Institute, Manila, The Philippines; 1982. 
Systematic Bacteriology (Krieg, N.R. and Holt, J.G., eds). 1984; pp. 199-210.

11. OCTA. 1970. Bacterial leaf blight of rice. Plant in Southeastern Asia. Overseas Technical Cooperation Agency, Tokyo, Japan. pp. 71.

12. Ninoliu DO, Ronald PC, Bogdanove AJ. Xanthomonas oryzae pathovars: model pathogens of a model crop. Molecular Plant Pathology. 2006;7:303- 24 . https://doi.org/10.1111/j.13643703.2006.00344.x.

13. Mew TW, Alvarez AM, Leach JE, Swings J. Focus on bacterial blight of rice. Plant Disease. 1993;77(1):5-12.https:// doi.org/10.1094/PD-77-0005

14. Ou SH. Rice Diseases. $2^{\text {nd }}$ ed, Commonwealth Mycological Institute, Kew, Surrey, England; 1985, p. 61-96.

15. Islam MR, Alam MS, Khan Al, Hossain I, Adam LR, Daayf F. Analyses of genetic diversity of bacterial blight pathogen, Xanthomonas oryzae pv. oryzae using IS 1112 in Bangladesh. Comptes Rendus Biologies. 2016 Sep 1;339(9-10):399-407.https:// doi.org/10.1016/j.crvi.2016.06.002

16. Noda T, Yamamoto T, Kaku H, Horino O. Geographical distribution of pathogenic races of Xanthomonas oryzae pv. oryzae in Japan in 1991. Japanese Journal of Phytopathology. 1996;62 (6):549-53. https://doi.org/10.3186/jjphytopath.62.549

17. Jalaluddin M, Kashem M. 1999. Pathogenic variability in Xanthomonas oryzae pv.oryzae in Bangladesh. The Indian Journal of Agricultural Sciences. 69:25-27.

18. Islam M, Islam N, Juthy P, Haque M, Rahman M. Identification of plant growth promoting antagonistic bacteria against Xanthomonas oryzae pv. oryzae in Bangladesh. Fundamental of Applied Agriculture. 2019; 4:1. https://doi.org/10.5455/faa.67224

19. Verdier V, Cruz CV and Leach JE. Controlling rice bacterial blight in Africa: Needs and prospects in Journal of Biotechnology. 2012;159:320-28. https://doi.org/10.1016/j.jbiotec.2011.09.020

20. Reddy PR. Kresek phase of bacterial blight of rice. Oryza. 1984;21:179-87.

21. Bharani M, Nagarajan P, Rabindran R, Saraswathi R, Balasubramanian $\mathrm{P}$, Ramalingam J. Bacterial leaf blight resistance genes (xa21, xa13 and xa5) pyramiding through molecular marker assisted selection into rice cultivars. Archives of Phytopathology and Plant Protection. 2010 Jul 1;43(10):1032-43. https:// doi.org/10.1080/03235400802285471

22. Alam MS, Islam MR, Hossain I, Bhuiyan MR, Khan MA. Pathotypic variation of Xanthomonas oryzae pv. oryzae in Bangladesh. Archives of Phytopathology and Plant Protection. 2016 Feb 25;49(14):31-42.https://doi.org/10.1080/03235408.2016.1150633

23. Vera Cruz CM. Bacteriological and pathological variation of Xanthomonas campestris pv. oryzae (Ishiyama) dye, the pathogen of bacterial blight of rice, MS thesis. Los Banios, Philippines, University of the Philippines, 1984.

24. Noda D, Ronald P, Bogdanove AJ. Pathogen profile Xanthomonus oryzae pathovars: model pathogen of a model crop. Molecular Plant Pathology. 2001;7:303-24. https://doi.org/10.1111/j.13643703.2006.00344.x

25. Haque MM., Masud MM., Hossain MI., Rashid MM, Alam MZ, Islam MR. Assessment of potentiality of known bacterial blight resistant genes against Xanthomonas oryzae pv. oryzae pathotypes exist in Bangladesh. Archives of Agriculture and Environmental Science. 2021;6(3):257-67. doi.org/10.26832/24566632.2021.060301

26. Brar DS, Khush GS. Alien introgression in rice. Oryza: from molecule to plant. 1997:35-47. https://doi.org/10.1007/978-94-0115794-0_4

27. Lee KS, Rasabandith S, Angeles ER, Khush GS. Inheritance of resistance to bacterial blight in 21 cultivars of rice. Phytopatholo- gy. $2003 \quad$ Feb;93(2):147-52. https://doi.org/10.1094/ PHYTO.2003.93.2.147

28. Busungu C, Taura S, Sakagami JI, Anai T, Ichitani K. Highresolution mapping and characterization of $x a 42$, a resistance gene against multiple Xanthomonas oryzae pv. oryzae races in rice (Oryza sativa L.). Breeding science. 2018:17094. https:// doi.org/10.1270/jsbbs.17094

29. Lee YH, Kolade OO, Nomura K, Arvidson DN, He SY. Use of dominant-negative HrpA mutants to dissect Hrppilus assembly and type III secretion in Pseudomonas syringae pv. tomato. Journal of Biological Chemistry. 2005 Jun 3;280(22):21409-17. https:// doi.org/10.1074/jbc.M500972200

30. Salzberg SL, Sommer DD, Schatz MC, Phillippy AM, Rabinowicz $\mathrm{PD}$, Tsuge S, Furutani A, Ochiai H, Delcher AL, Kelley D, Madupu $\mathrm{R}$. Genome sequence and rapid evolution of the rice pathogen Xanthomonas oryzae pv. oryzae PXO99 A. BMC Genomics. 2008 Dec;9(1):1-6. https://doi.org/10.1186/1471-2164-9-204

31. Ochiai H, Inoue Y, Takeya M, Sasaki A, Kaku H. Genome sequence of Xanthomonas oryzae pv. oryzae suggests contribution of large numbers of effector genes and insertion sequences to its race diversity. Japan Agricultural Research Quarterly: JARQ. 2005 Oct 31;39(4):275-87. https://doi.org/10.6090/jarq.39.275

32. Leach JE, White FF, Rhoads ML, Leung H. A Repetitive DNA Sequence Differentiates Xanthomonas campestris pv. oryzae from Other Pathovars of $X$. campestris. Molecular Plant-Microbe Interactions. 1990;3(4):238-46. https://doi.org/10.1094/MPMI-3-238

33. Yang Y, Gabriel DW. Intragenic recombination of a single plant pathogen gene provides a mechanism for the evolution of new host specificities. Journal of Bacteriology. 1995 Sep;177(17):4963 -8. https://doi.org/10.1128/jb.177.17.4963-4968.1995

34. Cruz CV, Ardales E, Skinner D, Talag J, Nelson R, Louws F, Leung $\mathrm{H}$, Mew T, Leach J. Measurement of haplotypic variation in Xanthomonas oryzae pv. oryzae within a single field by rep-PCR and RFLP analyses. Studies. 1996;15:18.

35. Hopkins CM, White FF, Choi SH, Guo A, Leach JE. Identification of a family of avirulence genes from Xanthomonas oryzae pv. oryzae. Molecular Plant-Microbe Interaction. 1992 Nov 1;5(6):451-59. https://doi.org/10.1094/MPMI-5-451

36. Lahaye T, Bonas U. Molecular secrets of bacterial type III effector proteins. Trends in plant Science. 2001 Oct 1;6(10):479-85. https://doi.org/10.1016/S1360-1385(01)02083-0

37. Chatelut M, Dournes JL, Chabanon G, Marty N. Epidemiological typing of Stenotrophomonas (Xanthomonas) maltophilia by PCR. Journal of Clinical Microbiology. 1995 Apr;33(4):912-14. https:// doi.org/10.1128/jcm.33.4.912-914.1995

38. Snelling AM, Gerner-Smidt P, Hawkey PM, Heritage J, Parnell P, Porter C, Bodenham AR, Inglis T. Validation of use of whole-cell repetitive extragenic palindromic sequence-based PCR (REPPCR) for typing strains belonging to the Acinetobactercal coaceticus-Acinetobacter baumannii complex and application of the method to the investigation of a hospital outbreak. Journal of Clinical Microbiology. 1996 May;34(5):1193-202. https:// doi.org/10.1128/jcm.34.5.1193-1202.1996

39. Louws FJ, Fulbright DW, Stephens CT, De Bruijn FJ. Differentiation of genomic structure by rep-PCR finger-printing to rapidly classify Xanthomonas campestris pv. vesicatoria. Phytopathology. 1995 May 1;85(5):528-36. https://doi.org/10.1094/Phyto-85528

40. Versalovic J, Koeuth T, Lupski R. Distribution of repetitive DNA sequences in eubacteria and application to finerpriting of bacterial enomes. Nucleic Acids Research. 1991 Dec 25;19(24):6823-31. https://doi.org/10.1093/nar/19.24.6823

41. Hulton CS, Higgins CF, Sharp PM. ERIC sequences: a novel family of repetitive elements in the genomes of Escherichia coli, Salmonella typhimurium and other enterobacteria. Molecular microbi- 
ology. 1991 Apr;5(4):825-34. https://doi.org/10.1111/j.13652958.1991.tb00755.x

42. Martin B, Humbert O, Camara M, Guenzi E, Walker J, Mitchell T, 5 Andrew P, Prudhomme M, Alloing G, Hakenbeck R, Morrison DA. A highly conserved repeated DNA element located in the chromosome of Streptococcus pneumoniae. Nucleic acids Research. 1992 Jul 11;20(13):3479-83. https://doi.org/10.1093/ nar/20.13.3479

43. Adachi N, Takashi OK. PCR-mediated detection of Xanthomonas oryzae pv. oryzae by amplification of the 16S-23S rDNA spacer region sequence. Journal of General Plant Pathology. 2000 Nov;66(4):303-09. https://doi.org/10.1007/PL00012969

44. Ogawa T, Khush GS. Major genes for resistance to bacterial blight in rice. Bacterial Blight of Rice, Proceedings of the International Workshop on Bacterial Blight of Rice. International Rice Research Institute, Manila, Philippines; 1988, P. 177-92.

45. Reimers PJ, Leach JE. Race-specific resistance to Xanthomonas oryzae pv. oryzae conferred by bacterial blight resistance gene $\mathrm{Xa}$ -10 in rice (Oryza sativa) involves accumulation of a lignin-like substance in host tissues. Physiological and Molecular Plant Pathology. 1991 Jan 1;38(1):39-55. https://doi.org/10.1016/S0885 $-5765(05) 80141-9$

46. Wang CL, Zhang Q, Zhou YL, Zhao BY. Genetic diversity of pathogen Xanthomonas oryzae pv. oryzae from southern regions of Yangtze river in China. Chinese Journal of Rice Scienc. 2001; 15: 131-36. https://doi.org/10.1016/S1672-6308(08)60031-1

47. Kauffman HE. An improved technique for evaluating resistance of rice varieties to Xanthomonas oryzae. Plant Disese Report. 1973; 57:537-41.

48. Cruz V, Raymundo AK, Leach JE. Nonradioactive DNA analysis using biotin labeling and chemiluminescent detection. International Rice Research Notes. 1994.

49. Hartl DL, Clark AW. Principle of Population Genetics, 3rd ed, Sinauer Associates, Sunderland, MA; 1997.

50. Woolhouse ME, Webster JP, Domingo E, Charlesworth B, Levin BR. Biological and biomedical implications of the co-evolution of pathogens and their hosts. Nature Genetics. 2002 Dec;32(4):56977. https://doi.org/10.1038/ng1202-569

51. Flor HH. Current status of the gene-for-gene concept. Annual Review of Phytopathology. 1971;9:275-96. https:// doi.org/10.1146/annurev.py.09.090171.001423

52. Bonas U, Stall RE, Staskawicz B. Genetic and structural characterization of the avirulence gene avrBs3 from Xanthomonas campestris pv. Vesicatoria Molecular and General Genetics MGG. 1989 Jul;218 (1):127-36. https://doi.org/10.1007/BF00330575

53. Versalovic J, Schneider M, De Bruijn FJ, Lupski JR. Genomic fingerprinting of bacteria using repetitive sequence-based polymerase chain reaction. Methods in Molecular and Cellular Biology. 1994 Jan 1;5(1):25-40.

54. Gillings M, Holley M. Repetitive element PCR fingerprinting (rep$P C R$ ) using enterobacterial repetitive intergenic consensus (ERIC) primers is not necessarily directed at ERIC elements. Letters in Applied Microbiology. 1997 Jul;25(1):17-21. https:// doi.org/10.1046/j.1472-765X.1997.00162.x

55. De Bruijn FJ. Use of repetitive (repetitive extragenic palindromic and enterobacterial repetitive intergeneric consensus) sequences and the polymerase chain reaction to fingerprint the genomes of Rhizobium meliloti isolates and other soil bacteria. Applied and
Environmental Microbiology. 1992 Jul;58(7):2180-87. https:// doi.org/10.1128/aem.58.7.2180-2187.1992

Murry MA, Zhang D, Schineider M, DeBruijn FJ. Use of repetitive sequences and the polymerase chain reaction (rep-PCR) to fingerprint the genomes of Frankia isolates. Symbiosis. 1995;9:22340.

57. Del Vecchio VG, Petroziello JM, Gress MJ, McCleskey FK, Melcher GP, Crouch HK, Lupski JR. Molecular genotyping of methicillinresistant Staphylococcus aureus via fluorophore-enhanced repetitive-sequence PCR. Journal of Clinical Microbiology. 1995 Aug; 33(8):2141-44. https://doi.org/10.1128/jcm.33.8.2141-2144.

58. Georgiou G. Expression of proteins in bacteria, land JL, Craik CS, editors.; In Principles and Practice of Protein Engineering. ClePlenum Press: New York; 1994.

59. Grover A, Azmi W, Gadewar AV, Pattanayak D, Naik PS, Shekhawat GS, Chakrabarti SK. Genotypic diversity in a localized population of Ralstonia solanacearum as revealed by random amplified polymorphic DNA markers. Journal of Applied Microbiology. 2006 Oct;101(4):798-806. https://doi.org/10.1111/j.13652672.2006.02974.x

60. Rademaker JL, Louws FJ, Schultz MH, Rossbach U, Vauterin L, Swings J, De Bruijn FJ. A comprehensive species to strain taxonomic framework for Xanthomonas. Phytopathology. 2005 Sep;95(9):1098-111. https://doi.org/10.1094/PHYTO-95-1098

61. Gonzalez C, Szurek B, Manceau C, Mathieu T, Séré Y, Verdier V. Molecular and pathotypic characterization of new Xanthomonas oryzae strains from West Africa. Molecular Plant-Microbe Interactions. 2007 May;20(5):534-46. https://doi.org/10.1094/MPMI-20-50534

62. George ML, Bustamam M, Cruz WT, Leach JE, Nelson RJ. Movement of Xanthomonas oryzae pv. oryzae in Southeast Asia detected using PCR-based DNA fingerprinting. Phytopathology. 1997 Mar;87(3):302-29. https://doi.org/10.1094/PHYTO.1997.87.3.302

63. Nayak P. Host-pathogen interaction in bacterial blight pathosystem in rice. Acta phytopathologica Etentomologica Hungarica. 1986;21(1-2):109-14.

64. Nelson RJ, Baraoidan MR, Cruz CM, Yap IV, Leach JE, Mew TW, Leung $\mathrm{H}$. Relationship between phylogeny and pathotype for the bacterial blight pathogen of rice. Applied and Environmental Microbiology. 1994 Sep;60(9):3275-83. https://doi.org/10.1128/ aem.60.9.3275-3283.1994

65. Ochiai H, Horino O, Miyajima K, Kaku H. Genetic diversity of Xanthomonas oryzae pv. oryzae strains from Sri Lanka. Phytopathology. $\quad 2000 \quad$ Apr;90(4):415-21. https://doi.org/10.1094/ PHYTO.2000.90.4.415

66. Yashitola J, Krishnaveni D, Reddy AP, Sonti RV. Genetic diversity within the population of Xanthomonas oryzae pv. oryzae in India. Phytopathology. 1997 Jul;87(7):760-65.https://doi.org/10.1094/ PHYTO.1997.87.7.760

67. Adhikari TB, Basnyat RC, Mew TW. Virulence of Xanthomonas oryzae $p v$. oryzae on rice lines containing single resistance genes and gene combinations. Plant Disease. 1999 Jan;83(1):46-50. https://doi.org/10.1094/PDIS.1999.83.1.46 